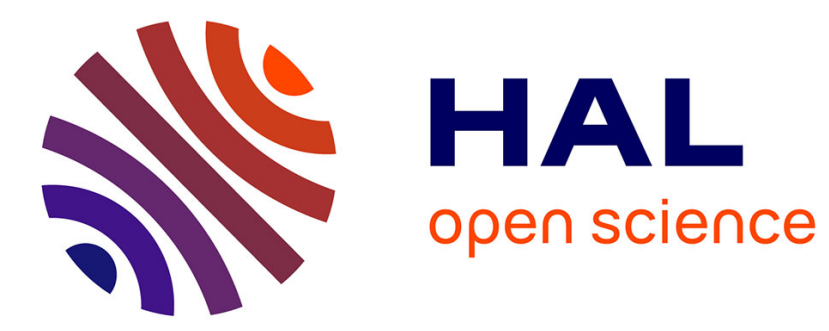

\title{
Ruminal methanogenesis and its alternatives
}

G Fonty, B Morvan

\section{To cite this version:}

G Fonty, B Morvan. Ruminal methanogenesis and its alternatives. Annales de zootechnie, 1996, 45 (Suppl1), pp.313-138. hal-00889640

\section{HAL Id: hal-00889640 https://hal.science/hal-00889640}

Submitted on 1 Jan 1996

HAL is a multi-disciplinary open access archive for the deposit and dissemination of scientific research documents, whether they are published or not. The documents may come from teaching and research institutions in France or abroad, or from public or private research centers.
L'archive ouverte pluridisciplinaire HAL, est destinée au dépôt et à la diffusion de documents scientifiques de niveau recherche, publiés ou non, émanant des établissements d'enseignement et de recherche français ou étrangers, des laboratoires publics ou privés. 


\title{
Ruminal methanogenesis and its alternatives
}

\author{
G Fonty, B Morvan \\ INRA, Laboratoire de Microbiologie, C.R. de Clermont-Ferrand-Theix \\ 63122 Saint-Genès-Champanelle, France
}

\begin{abstract}
Methanogenesis is the terminal step in carbon flow in many anaerobic habitats including marine and freshwater sediments, marshes and swamps, rice paddies, geothermal habitats, anaerobic sewage digestion systems and animal gastrointestinal tracts. Biological methanogenesis plays a major role in the carbon cycle on earth. Methane escaping from anaerobic habitats can serve as a carbon and energy source for aerobic methanotrophic bacteria or can escape to the atmosphere, where it is a major participant in atmospheric chemical reactions and is an important greenhouse gas (Zinder, 1993).

The rumen and the large intestine of humans and monogastric animals, do not completely convert organic matter to $\mathrm{CH}_{4}$ and $\mathrm{CO}_{2}$. They accumulate high concentrations of volatile fatty acids (c.a. $60 \mathrm{mM}$ acetate, $20 \mathrm{mM}$ propionate and $10 \mathrm{mM}$ butyrate) which are available to the animal host as an energy source. The predominant substrates for methanogens in these ecosystems are $\mathrm{H}_{2}$ and $\mathrm{CO}_{2}$. A major difference between intestinal ecosystems and complete bioconversion systems is the turnover time. Digestive ecosystems have turnover times of approximately 1 to 2 days, while in complete conversion systems the turnover times are weeks to months (Miller, 1991). Thus, the slowgrowing fatty acids oxiders and acetogenic methanogens cannot be sustained in intestinal ecosystems.
\end{abstract}

\section{Rumen methanogens}

Methanogens are a sub-group of the archaea domain (Woese et al, 1987). Bacteria and methanogenic archaea differ in the composition of their cellular constituents. The characteristic peptidoglycan polymer of the cell walls of bacteria is absent from archaea. The lipids of methanogens are glycerol ethers rather than glycerol esters. Ribosomal RNA nucleotide sequences of archaea and bacteria indicate early divergence of the two domains during evolution. The phylogenetic data based on rRNA analysis and nucleic acid hybridization, coupled with physiological, immunological and biochemical characteristics currently support the taxonomic organization of methanogenic archaea into three orders comprising six families. Nineteen genera containing more than 50 species have been described to date (Boone et al, 1993).

Methanogenic archaea are the dominant $\mathrm{H}_{2}$ utilizers in the rumen. However despite the economic implication of methanogens for agriculture, our knowledge of methanogen species in the rumen is still scarce. Our current information is based on a few isolates from a few animals. Hydrogenotrophic methanogens , which reduce $\mathrm{CO}_{2}$ to $\mathrm{CH}_{4}$, are responsible for the major part of rumen methanogenesis. Methanobrevibacter ruminantium (formerly Methanobacterium ruminantium) was the first methanogen isolated from the bovine rumen (Smith and Hungate, 1958). It was present in high numbers and formed $\mathrm{CH}_{4}$ from $\mathrm{H}_{2}$ and $\mathrm{CO}_{2}$. Strains of methanogenic archaea which had the morphological and physiological characteristics of Methanobrevibacter spp. but which did not react with rabbit antisera raised against $M$. ruminantium were also isolated from the bovine rumen (Lovley et al, 1984; Miller et al, 1986). Methanobrevibacter is considered to be the major methanogenic genus in the rumen (Miller, 1991). Paynter and Hungate (1968) reported the isolation of Methanomicrobium mobile from the rumen of a cow, and Methanosarcina species presumably growing on methylamines and methanol were found in low numbers $\left(10^{4} \mathrm{ml}^{-1}\right)$ in a cow rumen (Patterson and Hespell, 1979). Strains ressembling Methanobrevibacter species have also been isolated from the rumen contents of young lambs (Morvan et al, unpublished data), but up to now there is no information on the characteristics of the methanogens of the adult 
ovine rumen (Miller, 1994). In the rumen, some methanogens are associated with protozoa (Stumm et al, 1982). Methanogens appear in the rumen of new-born animals very soon after birth since they were found as early as two or three days of age in the lamb rumen (Fonty et al, 1987; Morvan et al, 1994). At the end of the first week of life their numbers reached $10^{6} \mathrm{ml}$ 1 rumen contents and when the animals were two-weeks old the methanogenic population was close to that observed in adult sheep.

\section{Biochemistry of ruminal methano- genesis}

$\mathrm{CO}_{2}$ is converted to $\mathrm{CH}_{4}$ by sequentially reduced intermediates. The reactions, enzymes and electron carriers involved in this process have been the subject of numerous studies during the past decades, and the results of these investigations on the biochemistry of methanogenesis have been intensively reviewed (Vogels et al, 1988; Thauer et al, 1993) and will not be detailed in this paper.

\section{Factors affecting methane production in the rumen}

Owing to the lack of fatty acid oxidizers and acetotrophic methanogens, the rumen can be considered as a truncated ecosystem when compared to an anaerobic digestor and considerably less $\mathrm{CH}_{4}$ is produced per unit carbon digested compared to the anaerobic digestor. However, because of the large amounts of plant material ingested, the rumen fermentations lead to the emission, by belching, of large volume of methane, approximately 200-400 liters per day from the bovine rumen (Miller, 1991; Tyler, 1991) which correspond to a production of 800 to 1600 liters of hydrogen. A sheep eructates approximately 50 liters of $\mathrm{CH}_{4}$ per day. According to Sauvant (1993) there are 65 liters of methane and 152 liters of $\mathrm{CO}_{2}$ produced in the rumen for each $\mathrm{kg}$ of organic matter fermented.

Ruminants are the second largest anthropogenic methane source in the world emitting $80 \mathrm{Tg} /$ year (15\% of the total) (Crutzen, 1994). This represents a lost opportunity for transforming more carbon into useful products, such as meat or milk during the natural fermentation of feed. It would appear that the total methane emissions from ruminants increases by about 0.5 to $1 \%$ per year. An estimation by Crutzen et al (1986) indicated that over the last century, $\mathrm{CH}_{4}$ emission by ruminants has increased 4 fold and has almost doubled within the past 40 years.

The effects of environmental factors on methanogenesis in the rumen are not well documented because it is difficult to design experiments that include the effects of $\mathrm{pH}$, toxic substances, composition of the diet etc.

However some factors which influence methane emission by ruminants have been investigated. The major factors are the followings :

- differences between animal species: The contributions of different animal species to global $\mathrm{CH}_{4}$ emissions are highly variable. Of the domestic species, cattle, with their large size and numbers, are the major contributions, producing $70 \%$ of the animal emissions. Smaller ruminant species, sheep and goats, produce approximately $13 \%$ of animal emissions, horses and mules appear to be the principal non ruminant methane emitters $(2 \%)$, followed by pigs (1\%). Crutzen et al (1986) estimate that wild ruminants globally produce about $5 \%$ of total animal methane. Cattle from developed countries produce more methane than the cattle from developing countries (Crutzen et al, 1986; Seiler, 1984).

- digestibility of feed intake: Approximatively 4 to 10 per cent of the gross energy ingested by dairy and feed cattle is lost in the form of methane (Vermorel, 1995). The more digestible the feed intake, the greater the proportion of its gross energy that is released in the form of methane. It must be noted, however, that the ingestion of highly digestible feedstuffs results in a high level of animal performance (Sauvant, 1993).

- feeding level: Blaxter and Clapperton (1965) demonstrated that the methane emission expressed as the percentage of gross energy decreases significantly with an increase in the level of intake, i.e. it is affected by the level of production and the rate of passage of the particle in the digestive tract. This means that for similar diets, ruminants at a high level of production convert a smaller proportion of ingested feed into methane.

- mode of production: According to Sauvant (1993), intensive animal production is not associated with increased methanogenesis. In 
fact, the reverse occurs if methane production is evaluated against the units of product produced.

- nature of the feed: Generally, for equal energy digestibility, low-fibre diets lead to a lower methane production than high fibre diets. Fat supplementation of the feed also reduces methanogenesis (Blaxter and Clapperton, 1965; Giger-Reverdin et al, 1992).

- composition of the rumen microbial population also affects the production of methane by ruminants. For example, in the absence of protozoa (defaunated animals) the ruminal methane emission is reduced, probably because several species of ciliates produce hydrogen. Although the physical associations between $\mathrm{H}_{2}$-producing species and methanogens are not essential for $\mathrm{H}_{2}$ transfer, close association between the two types of organisms may facilitate interspecies $\mathrm{H}_{2}$ transfer in the rumen (Itabashi et al, 1994; Miller, 1994). Attachment of methanogens to the surface of rumen protozoa has been observed (Stumm et al, 1982; Krumholz et al, 1983).

\section{Effects of methanogens on rumen fermentation. Interspecies electron transfer}

By using $\mathrm{H}_{2}$ for $\mathrm{CH}_{4}$ production, methanogens maintain a low partial pressure of $\mathrm{H}_{2}\left(\mathbf{1 0}^{-4} \mathrm{~atm}\right.$; $0,01 \mathrm{kPa})$ in the rumen. The interaction between $\mathrm{H}_{2}$-producing fermentative bacteria and $\mathrm{H}_{2}$-using methanogens is called «interspecies hydrogen transfer" (lanotti et al, 1973) and has a great influence on fermentation endproducts as well as on the ATP yield of fermentative microorganisms. Interspecies $\mathrm{H}_{2}$ transfer eliminates the formation of electron sink products (ethanol, lactate) formed during the reoxidation of NADH in monocultures of the fermenting microorganisms. For example, in pure culture Ruminococcus albus produces acetate, ethanol, $\mathrm{H}_{2}$ and $\mathrm{CO}_{2}$. When cocultured with a methanogen, its ethanol production ceases while the production of $\mathrm{H}_{2}$, acetate and ATP increases (Wolin and Miller, 1988). The anaerobic fungi, which are hydrogen producers, also interact with methanogens. In vitro, the association between fungi and methanogens leads to an increase in the fungal biomass (Bernalier et al, 1990) and to an increase in the rate and extent of cellulose breakdown. The fungal metabolism shifts towards a greater production of acetate at the expense of lactate and ethanol (Bauchop and Mountfort, 1981; Fonty et al, 1988; MarvinSikkema et al, 1990). Fermentation by other important microbes in the rumen, such as $R$. flavefaciens, Selemonas ruminantium influences the partial pressure of $\mathrm{H}_{2}$ and can result in interspecies transfer (Wolin and Miller, 1988). The effects of methanogens on cellulose degradation observed in vitro have also been demonstrated in vivo in the rumen of gnotobiotically-reared lambs (Fonty et al, 1994). These shifts in the metabolism of fermentative or cellulolytic $\mathrm{H}_{2}$-producing microorganisms probably play a significant role in regulating the relative amounts of acetate and propionate formed in the rumen.

\section{Possible solutions for the reduction of methane emission by ruminants}

Considerable research efforts have been devoted to the manipulation of rumen fermentations with the aim of reducing methane production and improving ruminant productivity. A low methane-high propionate pattern in the rumen indicates a fermentation with higher efficiency in terms of gross energy retained in non gaseous end-products (ørskov, 1975). Methanogenesis is a process which can be easily inhibited by many chemicals (halogenated methane analogue, sulphite, nitrate, unsaturated long-chain fatty acids, ionophore antibiotics etc ...). The effects of these compounds on rumen fermentation and animal performance have been intensively reviewed and will not be detailed in this paper (see review of Van Nevel and Demeyer, 1988). Current knowledge of intestinal fermentations in wood-feeding termites (Breznak, 1994) and in colonic fermentations of non methaneproducing human subjects (Durand and Bernalier, 1993; Wolin and Miller, 1994) suggests other strategies for reducing the contribution of ruminants to the global methane budget. In these ecosystems $\mathrm{H}_{2} / \mathrm{CO}_{2}$-utilizing acetogenic bacteria are frequently the terminal electron-accepting organisms instead of methanogens. Acetogenic bacteria use the $\mathrm{H}_{2}$ produced by the fermentative bacteria to reduce $\mathrm{CO}_{2}$ to acetate by the Wood-Ljungdahl pathway $\left(2 \mathrm{CO}_{2}+4 \mathrm{H}_{2} \rightarrow \mathrm{CH}_{3} \mathrm{COOH}+2 \mathrm{H}_{2} \mathrm{O}\right)$ (Ljungdahl, 1986). 
$\mathrm{H}_{2}-\mathrm{CO}_{2}$-utilizing acetogenic bacteria are present in the rumen but it is difficult to predict their $\mathrm{H}_{2}$-utilizing acetogenic activity in vivo since they are capable of utilizing numerous other substrates such as carbohydrates and aromatic compounds for their growth (Mackie and Bryant, 1994; Rieu-Lesme et al, 1994; Morvan, 1995). The main $\mathrm{H}_{2}$-using acetogenic species described to date are : Acetitomaculum ruminis, Eubacterium limosum, Clostridium pfennigii (Mackie and Bryant, 1994). Some other isolates which probably belong to a new species are phylogenetically close to Clostridium coccoïdes, Ruminococcus (Peptostreptococcus) productus or Ruminococcus hansenii and are included in the cluster XIV of Clostridium (Bernalier et al, 1995; Rieu-Lesme et al, this issue).

Acetogenic hydrogenotrophic bacteria are among the earliest bacterial species able to colonize the rumen after birth. In newborn lambs they are present in quite high numbers $\left(10^{5}-10^{6} \mathrm{ml}^{-1}\right)$ one day after birth (Morvan et al, 1994). In the adult ruminant, the acetogenic population, estimated by the most probable number (MPN) (Doré et al, 1995) (growing on $\mathrm{H}_{2}-\mathrm{CO}_{2}$ and producing acetate) is usually low and variable (Morvan, 1995). Prins and Lankhorst (1977) measured $\mathrm{H}_{2}-\mathrm{CO}_{2}$-utilizing acetogenic activity by incubating ruminal contents with $\mathrm{H}_{2}$ and ${ }^{14} \mathrm{CO}_{2}$ and found that only $5 \%$ of the label in soluble product was incorporated into acetate. In contrast, Leedle and Greening (1988) found high numbers of presumably acetogenic bacteria in the rumen of steers. The population was consistently higher in steers fed a high-grain diet than in animals fed a high-forage diet $\left(11.3 \times 10^{8}\right.$ versus $6.0 \times 10^{8} \mathrm{~g}^{-1}$ rumen contents). Thus, acetogenesis could be an alternative for $\mathrm{H}_{2}$ utilization in the rumen.

The problem for the microbiologist is to understand why acetogenesis outcompetes methanogenesis in the human colon and the termite hindgut but does not in the rumen. This requires an evaluation of factors which affect the successful competition for hydrogen. Thermodynamics, hydrogen thresholds, kinetic parameters $\left(\mathrm{V}_{\mathrm{m}}, \mathrm{K}_{\mathrm{m}}\right)$ and mixotrophy are some of the factors involved. Acetogenesis is thermodynamically possible under the in situ conditions of the rumen and could theoretically take place (Mackie and Bryant, 1994). Hydrogen thresholds for acetogenic bacteria are usually higher than those for methanogenic strains, and usually higher than the ruminal $\mathrm{H}_{2}$ concentration (Boccazzi et al, 1991; Mackie and Bryant, 1994; Morvan and Fonty, unpublished results). However, the threshold value varies widely according to the strain and some acetogenic strains have a $\mathrm{H}_{2}$-threshold value comparable to those of methanogenic strains (Boccazzi et al, 1991; Morvan and Fonty, unpublished results). Little is known of the kinetic parameters for $\mathrm{H}_{2}-\mathrm{CO}_{2}$ utilizing ruminal acetogenic bacteria.

In a similar manner to methanogens, in vitro, $\mathrm{H}_{2}$-using acetogenic bacteria are able to interact synergistically with cellulolytic $\mathrm{H}_{2}$-producing microorganisms ( $R$. albus, R. flavefaciens, Neocallimastix frontalis) (Bernalier et al, 1993; Morvan and Fonty, unpublished results). In their presence, the rate of cellulose breakdown is enhanced and the metabolism of the cellulolytics is shifted towards a greater production of acetate.

Some other ruminal $\mathrm{H}_{2}$-utilizing bacterial species such as Wolinella succinogenes, Selenomonas ruminantium, Anaerovibrio lipolytica which are not acetogenic, are also members of the ruminal ecosystem (Stewart and Bryant, 1988). However, their ecological role in hydrogen utilization in vivo remains to be elucidated. Sulfate-reducing bacteria are present in the rumen in low numbers (Morvan et al, 1995, unpublished data). They probably do not make a significant contribution to hydrogen utilization since the ruminal concentration of sulfate is low (Durand and Kawashima, 1980). Moreover, sulfatereduction cannot be an alternative to methanogenesis because the accumulation of sulfurs is toxic for both the animal host and the rumen microbes.

\section{Conclusion}

Herbivorous animals, especially ruminants produce far more methane than other animals. Farm cattle represent by far the greatest methane-producing animal population on the earth. However if related to the same level of protein produced for man, small ruminants are in all likelihood just as methanogenous.

Reduction of methane emission by animal populations is an extremely complex problem. Individual technical solutions (nature of the diet, use of feed additives...) can help 
to reduce methanogenesis. Research is necessary to establish a set of recommendations on this subject. The microbial potential for a $\mathrm{CO}_{2}$-acelate fermentation already exists in the rumen and biotechnology could be applied to replace the methanogenic population of the rumen with the population which carries out the $\mathrm{CO}_{2}$-acetate fermentation. More research is required to understand the ecology and physiology of acetogenic bacteria and to devise practical methods for effecting a shift to the hydrogenotrophic acetate production, in order to increase the efficiency of ruminant production and decrease their contribution to the global methane budget.

\section{Literature cited}

Bauchop T, Mountfort DD (1981) Cellulose fermentation by a rumen anaerobic fungus in both the absence and presence of rumen methanogens. Appl Environ Microbiol 42, 1101 1110

Bernalier A, Fonty G, Gouet Ph (1990) Cellulose degradation by two anaerobic fungi in monoculture or in coculture with rumen bacteria. Anim Feed Sci Tech 32, 131-136

Bernalier A, Fonty G, Gouet Ph (1993) Effect of Eubacterium limosum, a ruminal hydrogenotropic bacterium, on the degradation and fermentation of cellulose by three species of rumen anaerobic fungi. Reprod Nutr Dev 33, 577-584

Bernalier A, Rieu-Lesme F, Willems A, Fonty $G$, Collins MD (1995) Diversity of $\mathrm{H}_{2} / \mathrm{CO}_{2}$-utilizing acetogenic bacteria from the digestive tract of animals and man. In: Proceeding of the International Symposium on Exploration of Microbial diversity, Groslar, June 12-15, Germany,

Blaxter KL, Clapperton JL (1965) Prediction of the amount of methane produced by ruminants. Brit $J$ Nutr 19, 511-522

Boccazzi P, Patterson JA, Wilsey BJ, Schaeffer DM (1991) Hydrogen threshold values for one methanogenic and form acetogenic isolates from the rumen. In: Rumen fonction conference, Chicago, USA, 37

Boone DR, Whitman WB, Rouvière $P$ (1993) Diversity and taxonomy of methanogens. In: Methanogenesis (Ferry JG, ed) Chapman of Hall, New York, London, 35-80

Breznak JA (1994) Acetogenesis from carbon in termite guts. In: Acetogenesis (Drake HL, ed) Chapman and Hall, New-York, 303-330

Crutzen JP (1994) The role of ruminants as a source of methane relevance to atmosphere chemistry. Proc Soc Nutr Physiol 3, 175

Crutzen PJ, Aselmann I, Seiler W (1986) Methane production by domestic animals, wild ruminants, other herbivorous fauna and humans. Tellus 33B, 271-284

Doré J, Morvan B, Rieu-Lesme F, Goderel I, Gouet Ph, Pochart $P$ (1995) Most pobable number enumeration of $\mathrm{H}_{2}$-utilizing acetogenic bacteria from the digestive tract of animals and man. FEMS Microbiol Lett 130, 7-12

Durand M, Kawashima R (1980) Influence of minerals in rumen microbial digestion. In: Digestive physiology and metabolism in ruminants (Ruckebush $Y$, Thivend $P$, eds) MTP Press Limited, Lancaster, 375-408

Durand M, Bernalier A (1993) Reductive acetogenesis in animal and human gut. In: Physiological and Clinical Aspects of Short Chain Fatty Acid Metabolism (Cummings $\mathrm{JH}$, Rombeau $\mathrm{J}$ L, Sakaha T, eds) Cambridge University Press, Cambridge, 107-117

Fonty G, Gouet Ph, Jouany JP, Senaud J (1987) Establishment of the microflora and anaerobic fungi in the rumen of lambs. J Gen Microbiol 133, 1835-1843

Fonty G, Gouet Ph, Santé V (1988) Influence d'une bactérie méthanogène sur l'activitè et le métabolisme de deux espèces de champignons cellulolytiques du rumen. Résultats préliminaires. Reprod Nutr Dev 28, 133-134

Fonty G, Williams AG, Bonnemoy F, Morvan B, Gouet Ph (1994) Effects of methanogens on microbial activities in the rumen of gnotobiotically-reared lambs. Proc Soc Nutr Physio/ 3, 178

Giger-Reverdin S, Vermorel M, Sauvant D, (1992) Facteurs de variations de la production de méthane au cours de la digestion des aliments composés chez les ruminants. Ann Zootech 41, 37-38

Ianotti EL, Kafkewitz D, Wolin MJ, Bryant MP (1973) Glucose fermentation products of Ruminococcus albus grown in continous culture with Vibrio succinogenes, changes caused by interspecies transfer of $H_{2}$. J Bacteriol 114, 1231-1240

Itabashi $\mathrm{H}$, Wahia $\mathrm{Y}$, Takenaka A, Oda $\mathrm{S}$, Ishibashi $\mathrm{T}$ (1994) Effects of a controlled fauna on methanogenesis, fibre digestion and rate of growth in calves. Proc Nutr Soc Physiol 3, 179

Krumholz LR, Forsberg CW, Veira DM (1983) Association of methanogenic bacteria with rumen protozoa. Can J Microbiol 29, 676-680

Leedle JAZ, Greening RC (1988) Postprandial changes in methanogenic and acetogenic bacteria in the rumen of steers fed high- or lowforage diets once daily. App/ Environ Microbiol $54,502-506$ 
Ljungdahl LG (1986) The autotrophic pathway of acetate synthesis in acetogenic bacteria. Ann Rev Microbiol 40, 415-450

Lovley DR, Greening RC, Ferry JG (1984) Rapidly growing rumen methanogenic organisms that synthetizes coenzyme $M$ and has a high affinity for formate. Appl Environ Microbiol 48, 81-87

Mackie RI, Bryant MP (1994) Acetogenesis and the rumen: syntropic relationship. In: Acetogenesis (Drake HL, ed) Chapman and Hall, New York, 331-364

Marvin-Sikkema FD, Richardson AJ, Stewart CS, Gottschal JC, Prins RA (1990) Influence of hydrogen-consuming bacteria on cellulose degradation by anaerobic fungi. Appl Environ Microbiol 56, 3793-3797

Miller TL, Wolin MJ, Hongxue Z, Bryant MP (1986) Characteristics of methanogens isolated from bovine rumen. Appl Environ Microbiol 51, 201 202

Miller TL (1991) Biogenic sources of methane. In: Microbial Production and Consumption of Greenhouse Gases, Methane, Nitrogen Oxides and Halomethanes (Rogers JE, Whitman WB, eds) American Society for Microbiology, Washington DC, $175-187$

Miller TL (1994) Ecology of methane production and hydrogen sinks in the rumen. Proc Soc Nutr Physiol 3, 176

Morvan B (1995) Ecologie et physiologie des microorganismes hydrogénotrophes des écosystèmes digestifs. Etude particulière de l'écosystème ruminal. Thèse de Doctorat, Université Claude Bernard, Lyon I,

Morvan B, Doré J, Rieu-Lesme F, Foucat L, Fonty G, Gouet Ph (1994) Establisment of hydrogenutilizing bacteria in the rumen of the newborn lamb. FEMS Microbiol Lett 117, 249-255

Ørskov ER (1975) Manipulation of rumen fermentation for maximum food utilization. World Rev Nutr Diet 22, 153-182

Patterson JA, Hespell RB (1979) Trimethylamine and methylamine as growth substrates for rumen bacteria and Methanosarcina barkeri. Curr Microbiol 3, 79-83

Paynter JB, Hungate RE (1968) Characterisation of Methanobacterium mobilis, sp. nov., isolated from the bovine rumen. J Bacteriol 95, 19431951

Sauvant D (1993) La production de méthane dans la biosphère, le rôle des animaux d'élevage. Courrier de la cellule Environnement de I'INRA, $18,65-70$
Seiler W (1984) Contribution of biological processes to the global budget of $\mathrm{CH}_{4}$ in the atmophere. In: Current Perspectives in Microbial Ecology (Klugg $\mathrm{MJ}$, Reddy CA, eds) American Society for Microbiology, Washington DC, 468-477

Smith $\mathrm{PH}$, Hungate $\mathrm{RE}$ (1958) Isolation and characterisation of Methanobacterium ruminantium n. sp.. J Bacteriol 75, 713-718

Stewart CS, Bryant MP (1988) The rumen bacteria. In: The Rumen Microbial Ecosystem (Hobson PN, ed) Elsevier Applied Science, London, New York, 21-75

Stumm CK, Cijzen HJ, Vogels GD (1982) Association of methanogenic bacteria with ovine rumen ciliate. Br J Nutr 47, 95-99

Thauer RK, Hedderich R, Fisher R (1993) Reactions and enzymes involved in methanogenesis from $\mathrm{CO}_{2}$ and $\mathrm{H}_{2}$. In: Methanogenesis (Ferry JG, ed) Chapman and Hall, London, 209-252.

Tyler SG (1991) The global methane budget. In: Microbial Production and Consumption of Greenhouses Gases, Methane, Nitrogen Oxides and Halomethanes (Rogers JE, Whitman WB, eds) American Society for Microbiology, Washington DC, 7-38

Van Nevel CJ, Demeyer DI (1988) Manipulation of rumen fermentation. In: The Rumen Microbial Ecosystem (Hobson PN, ed) Elsevier Applied Science, London, New York, 387-443

Vermorel M (1995) Emissions annuelles de méthane d'origine digestive par les bovins en France. Variations selon le type d'animal et le niveau de production. Prod Anim 8(4), 265-272

Vogels GD, Keltjens JT, Van der Drift C (1988) Biochemistry of methane production. In: Biology of Anaerobic Microorganisms (Zehnder AJB, ed) Wiley, New-York, 707-770

Woese CR, Kandler O, Wheelis JL (1990) Towards a natural system of organisms, proposal for the domains Archaea, Bacteria and Eucarya. Proc Nat Acad Sci USA 87, 4576-4579

Wolin MJ, Miller TL (1988) Microbe-Microbe interactions. In: The Rumen Microbial Ecosystem (Hobson PN, ed) Elsevier Applied Science, London, New-York, 343-359

Wolin MJ, Miller TL (1994) Acetogenesis from $\mathrm{CO}_{2}$ in the human colonic ecosystem. In: Acetogenesis (Drake HL, ed) Chapman and Hall, New York, London, 365-385

Zinder SH (1993) Physiological ecology of methanogens. In: Methanogenesis (Ferry JG, ed) Chapman of Hall, New York, London, 128-206 